\title{
Matematikai kiegészítések a harmonikus rezgőmozgás tárgyalásához
}

\author{
Barta Edit \\ Soproni Egyetem Informatikai és Matematikai Intézet \\ barta.edit@uni-sopron.hu
}

\begin{abstract}
ÖSSZEFOGLALÓ. Matematika és fizika oktatóként gyakran tapasztalom, hogy az a tudásbázis, amelyet a hallgatók középiskolából magukkal hoznak, majd az egyetemen a matematika kurzusokon elsajátítanak, kevésnek bizonyul ahhoz, hogy a komolyabb matematikai eszközöket is alkalmazó szakmai tárgyak némely levezetését megértsék. A számos eset közül most speciálisan a harmonikus rezgőmozgás kapcsán felmerülő matematikai megértési problémákhoz szeretnék segítségként néhány kiegészítést nyújtani.
\end{abstract}

ABSTRACT. It is often the case that the mathematical background of our university students is insufficient to understand the topics of certain subjects. A typical example of this is the harmonic oscillatory motion in physics. We provide some additional information to help in discussing it.

\section{Bevezetés}

E cikk megírására egy személyes emlék motivált. Immár több mint húsz éve, egyetemünk akkori Fizika-Elektrotechnika Tanszékén PhD-hallgatóként magam is bent ültem Papp György professzor úr Fizika I. tárgyának előadásain. Egyik alkalommal helyettesítenem kellett őt, és éppen a csillapított harmonikus rezgőmozgás témáját kellett előadnom az akkori hallgatóságnak. Segítségként megkaptam az ő saját kézzel írott jegyzeteit, amelyben a téma kemény matematikai tárgyalással szerepelt. Megértése sokkal komolyabb matematikai elöismereteket igényelt, mint amit a hallgatók akkor (és most) a matematika kurzusokon elsajátíthatnak. A három rezgéssel kapcsolatos téma (harmonikus rezgőmozgás, csillapított rezgések, kényszerrezgések) differenciálegyenletének megoldása sokban eltért a matematika órákon tanult módszerektől, és a komplex számok mélyebb ismeretét (pl. az Euler-alakkal való számolást), a komplex függvénytanban való alapjártasságot is igényelt volna. Nem véletlen hát, hogy éveken át ez a három tétel volt az, amelyet a legtöbb hallgató visszaadott a vizsgán, ha véletlenül közülük húzott. (Holott a teljes levezetés kihagyásával, csak magának a differenciálegyenletnek a felírásával és a megoldásként kapott kinematikai mozgásegyenletek elemzésével is szép osztályzatot lehetett kapni.)

Akkortájt fizikát és matematikát is oktattam, aztán évekig csak fizikát, s most néhány éve csak matematikát. Volt alkalmam belelátni néhány tantárgy (fizika, elektrotechnika, mechanika tantárgyai) matematikai módszereibe. A tapasztalatom az, hogy azon témák esetén, amelyek matematikai levezetéseket is igényelnek, módszereiket tekintve sokszor eltérnek a matematikából tanultaktól. Az egyik esetben a levezetésekre nem fektetnek túl nagy hangsúlyt, azokat átugorva legfeljebb hivatkoznak rá, hogy ,a matematikából tanult módon” ez és ez a végeredmény adódik, vagy csak az eredményt közlik, majd a „behelyettesítéssel meggyőződhetünk ennek helyességéről” kijelentéssel lépnek tovább. Ilyenkor annak ellenére, 
hogy matematikából hivatkozunk rá, hogy az éppen tanított anyag hol kerülhet elő a gyakorlatban, de legalább is további tanulmányaik során, a hallgatónak az a téves érzete támadhat, hogy a matematikára nincs is szükség a szakmai életben. A másik eset ennek ellenkezője, amikor a levezetés nagyobb matematikai alaptudást igényelne, mint amellyel a hallgató rendelkezik. Így az elhangzottakat nem tudja már meglévő ismerethez kötni, az új anyag „lóg a levegőben”, a levezetés megértése helyett kénytelen azt bemagolni. Az így megszerzett tudásból aztán hiányzik az az algoritmikus gondolkodásmód, amely lehetővé teszi, hogy más hasonló problémákra is alkalmazni tudjuk.

Terjedelmi okokból nincs lehetőségem mindazon hiányosságok bemutatására, amelyek egyetemünk hallgatói számára nehézzé teszik egy-egy téma megértését. A fenti személyes emlék miatt a harmonikus rezgőmozgás, mint oktatandó téma kicsit a szívemhez nőtt. Ezért ehhez a témához kapcsolódóan szeretnék rámutatni azokra a hiányzó matematikai anyagrészekre, amelyek jelenleg nem szerepelnek a tananyagban, ismeretük viszont elengedhetetlen a tárgyalásmód megértése szempontjából.

\section{A harmonikus rezgőmozgás szokásos matematikai leírásai}

\subsection{Kinematikai tárgyalásmód - a középiskolákból hozott ismeret}

A harmonikus rezgőmozgásról szinte mindenkinek a rugóra akasztott test mozgása jut eszébe. Maradjunk is ennél az egyszerü esetnél, amikor a tömegpont egy egyenes mentén végez rezgést. Középiskolákban a mozgás kinematikai leírása során a kitérés-idő, a sebesség-idő és a gyorsulás-idő függvényeket azon felismerés alapján vezetik le, hogy minden rugóra akasztott test mozgásához hozzárendelhető egy olyan egyenletes körmozgás (az ún. referencia körmozgás), amelynél a körmozgást végző pontnak és a rugón mozgó pontnak a körpálya síkjába eső függőleges egyenesre eső vetületei egybeesnek. Vagyis a rugóra akasztott test kitérés-, sebesség- és gyorsulás-idő függvényei megegyeznek az egyenletes körmozgást végző pont vetületének ugyanezen függvényeivel. A mozgások összehasonlítására a világhálón több bemutató anyag is található (pl. [1], [2]), s a levezetések is több tankönyvben olvashatók (pl. [3], [4], [5]). Ezek alapján a rugóra akasztott test kitérés-idő függvénye:

$$
x(t)=A \sin \left(\omega t+\varphi_{0}\right)
$$

ahol $A$ a mozgás amplitúdója, vagyis a maximális kitérés, $\omega$ a referencia körmozgás szögsebessége, amit a harmonikus rezgőmozgásnál körfrekvenciának nevezünk, $\varphi_{0}$ pedig a fázisállandó, más néven kezdőfázis. Ez utóbbi függ attól, hogy a mozgást mely időpillanatban kezdjük vizsgálni. A szinusz argumentuma a mozgás fázisa. Itt vezetik be a rezgésidő vagy periódusidő és a frekvencia fogalmát és kifejezéseit is. Ez a harmonikus rezgőmozgás kinematikai megközelítése, azok az összefüggések, amelyeket a középiskolából jött hallgatók magukkal hoznak, ismernek.

Mitől „harmonikus” ez a rezgés? Pontosan attól, hogy a kitérés az idő szinuszos függvénye. A harmonikus rezgést más néven szinuszrezgésnek is nevezik (ld. [6] 37. old.) Tágabb értelemben harmonikus rezgésről akkor beszélünk, ha a mozgás valamely jellemzője, például a koordináta az időnek szinuszos vagy koszinuszos függvénye ([7] 8. old.). Ezek alapján bármely fizikai mennyiség, amelynek időbeli változását az

$$
x(t)=A \sin \left(\omega t+\varphi_{0}\right) \text { vagy az } x(t)=B \cos \left(\omega t+\varphi_{0}\right)
$$

kifejezés valamelyike írja le, harmonikus rezgést végez. Az $x(t)$ nem csak a rugóra akasztott test kitérése lehet, hanem többek között a matematikai (fonál-) és a fizikai inga szögkitérése, a 
torziós inga elcsavarodási szöge, váltakozó áramú hálózatoknál az áramerősség vagy a feszültség, a kondenzátorlemezeken tárolt töltésmennyiség vagy a lemezek közötti elektromos térerősség, a tekercsben felépülő mágneses indukció, stb. Ezekben a mennyiségekben az a közös, hogy hasonló matematikai apparátussal írhatók le, vagyis ha egyet megtanultunk közülük, akkor annak analógiájára a többit is hasonlóan lehet tárgyalni.

\subsection{Dinamikai tárgyalásmód és annak matematikai kiegészítése}

Elöször szögezzük le, hogy a továbbiakban is csak az úgynevezett egy szabadságfokú mechanikai harmonikus rezgésekről lesz szó, amikor a pontszerünek tekintett test egy egyenes mentén mozdul el, és ennek is azzal a legegyszerúbb esetével foglalkozunk, amikor a rezgőmozgást végző pontra nem hat sem csillapító, sem kényszererő. Ezt a mozgást csillapítatlan szabadrezgésnek is nevezik.

A mozgás vizsgálatát a dinamika alapegyenletéből kiindulva végezzük. Ez a tárgyalási mód egyik szép példája a másodrendü, lineáris, állandó együtthatós differenciálegyenletek alkalmazásának, melyet a Matematika 1. tantárgy előadásán be is mutatunk ([8], 72-73. old.). Hogy az anyagot egyben lássuk, fussunk most át ezen a levezetésen!

A rugó legyen vízszintes helyzetü, a hozzá rögzített tömegpont pedig súrlódásmentes felületen mozogjon. Egyensúlyi helyzetben a test nyugalomban van, a rugó nyújtatlan. Az $x$ tengelyt célszerü a rugó hosszirányában, kezdőpontját pedig a test egyensúlyi helyzetében felvenni. Ha a testet kitérítjük ebből a helyzetéből, megnyújtva (vagy összenyomva) ezzel a rugót, akkor rá egy a kitéréssel arányos, vele ellentétes irányú erő hat, melynek alakja

$$
F=-D x
$$

ahol $D$-t most nevezzük rugóállandónak. (Megjegyzés: $D$ elnevezése nem egységes a szakirodalmakban, tankönyvekben. Bosznay a [7] 16-17. oldalán $c$-vel jelölve $D$ reciprokát használja a képletben és azt nevezi rugóállandónak. [6] 71. oldalán a lineáris erőtörvényben már a $D$ jelölést találjuk direkciós erő megnevezéssel, míg a rugóállandó kifejezést itt is ennek reciprokaként említi. Az újabb [4] tankönyv 19. oldalán szintén csak a $D$ jelölés fordul elö a reciprok megemlítése nélkül, direkciós állandónak nevezve azt, és zárójelben, mintegy szinonimaként teszi mellé a rugóállandó kifejezést.) Elengedve a testet a kitérés időben változni fog. A cél a kitérés időbeli függésének, azaz az $x(t)$ függvénynek a megadása. Newton II. törvénye $\left(\sum F=m a\right)$ alapján felírva a dinamika alapegyenletét, figyelembe véve, hogy a gyorsulás a kitérés idő szerinti második deriváltja $(a=\ddot{x})$, az

$$
m \ddot{x}=-D x
$$

differenciálegyenlethez jutunk. A tömeggel leosztva, az egyenletet átrendezve és bevezetve az $\omega=\sqrt{\frac{D}{m}}$ jelölést, kapjuk az

$$
\ddot{x}+\omega^{2} x=0
$$

másodrendü, lineáris, állandó együtthatós homogén differenciálegyenletet. Eddig volt a fizika, most jön a matematika. A karakterisztikus egyenlet:

$$
\lambda^{2}+\omega^{2}=0
$$

melynek megoldása egy komplex konjugált gyökpár:

$$
\lambda_{1,2}= \pm i \omega
$$


Ezzel a differenciálegyenlet általános megoldása:

$$
x(t)=c_{1} \cos (\omega t)+c_{2} \sin (\omega t) .
$$

A végeredményt a [8] jegyzet egy speciális kezdeti feltétel esetén adja meg, nevezetesen amikor az időt a test elengedésének pillanatában kezdjük mérni. Ekkor a kitérés maximális, azaz $A$, a sebesség pedig nulla. Ezzel a kitérés-idő függvény:

$$
x(t)=A \cos (\omega t) .
$$

A példa eddig tart. A levezetés didaktikailag is korrekt, hiszen minden lépés csak olyan ismereteket igényel, melyet a hallgatóknak elötte már átadtunk illetve középiskolában már átadtak. Abban a hallgatóban, aki még emlékszik a középiskolában tanult (1) összefüggésre, felmerülhet a kérdés, hogy miért nem azt kaptuk meg. Válaszként mondhatjuk, hogy a „koszinusz függvény is szinusz, csak el van tolva $\pi / 2$-vel” (gondoljunk a két szögfüggvény grafikonjára és a függvénytranszformációkról tanultakra!), vagyis ez a megoldás átírható az

$$
x(t)=A \sin \left(\omega t+\frac{\pi}{2}\right)
$$

alakra, ahol $\pi / 2$ a kezdőfázis. Ha a témát továbbra is didaktikusan kívánjuk tárgyalni, akkor meg kell mutatnunk azt is, hogy nem csak ennél a speciális indításnál, hanem tetszőleges kezdeti feltételek esetén is az (1)-gyel megegyező alakú kitérés-idő függvényt kapunk. Ehhez a kezdeti feltételeket a következö általános alakban vegyük fel:

$$
\left.\begin{array}{l}
x(0)=x_{0} \\
v(0)=\dot{x}=v_{0}
\end{array}\right\}
$$

A $t=0$-t behelyettesítve az (5) általános megoldásba $c_{1}=x_{0}$ adódik. Ezt behelyettesítve ugyanoda, majd deriválva a kifejezést kapjuk a sebességet:

$$
\dot{x}(t)=-\omega x_{0} \sin (\omega t)+\omega c_{2} \sin (\omega t) .
$$

Ebbe helyettesítve a sebességre vonatkozó kezdeti feltételt $c_{2}=\frac{v_{0}}{\omega}$ adódik. Ezzel a (2) differenciálegyenlet megadott általános kezdeti feltételeket is kielégítő partikuláris megoldása:

$$
x(t)=x_{0} \cos (\omega t)+\frac{v_{0}}{\omega} \sin (\omega t) .
$$

Ez a mozgásnak sem az amplitúdójáról, sem a kezdőfázisáról egyelőre még nem árul el semmit, viszont azok lényegesebb információt hordoznak a mozgásról, mint az, hogy egy önkényesen választott 0 időpontban mennyi a kitérés és a sebesség. Ez is indokolja a kifejezés átalakításának szükségességét, méghozzá didaktikai okok miatt olyan eszközök használatával, amelyeknek a hallgató feltehetően már birtokában van. Ehhez hajtsunk végre egy egyszerüen megérthető trigonometrikus átalakítást! Tekintsük az 1. ábrán látható derékszögü háromszöget, amelynek két befogója a (7) kifejezés jobb oldalán a szinusz és koszinusz függvények együtthatói, az $x_{0}$ oldallal szemközti szög pedig legyen $\varphi_{0}$. Ekkor Pitagorasz tétele alapján az átfogó $\sqrt{x_{0}^{2}+\left(\frac{v_{0}}{\omega}\right)^{2}}$ lesz. 


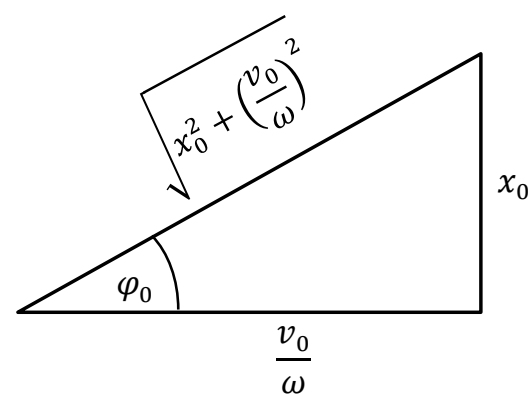

1. ábra.

Az ábrából az is látható, hogy

$$
\sin \varphi_{0}=\frac{x_{0}}{\sqrt{x_{0}^{2}+\left(\frac{v_{0}}{\omega}\right)^{2}}}, \text { és } \cos \varphi_{0}=\frac{\frac{v_{0}}{\omega}}{\sqrt{x_{0}^{2}+\left(\frac{v_{0}}{\omega}\right)^{2}}} .
$$

Emeljük ki a (7) egyenlet jobb oldalán az átfogónak megfelelő kifejezést, majd helyettesítsük be az együtthatók helyére (8) alapján a $\varphi_{0}$ szögfüggvényeit!

$$
\begin{gathered}
x(t)=\sqrt{x_{0}^{2}+\left(\frac{v_{0}}{\omega}\right)^{2}}\left(\frac{x_{0}}{\sqrt{x_{0}^{2}+\left(\frac{v_{0}}{\omega}\right)^{2}}} \cos (\omega t)+\frac{\frac{v_{0}}{\omega}}{\sqrt{x_{0}^{2}+\left(\frac{v_{0}}{\omega}\right)^{2}}} \sin (\omega t)\right), \\
x(t)=\sqrt{x_{0}^{2}+\left(\frac{v_{0}}{\omega}\right)^{2}}\left[\sin \varphi_{0} \cos (\omega t)+\cos \varphi_{0} \sin (\omega t)\right] .
\end{gathered}
$$

A szögletes zárójelben álló kifejezés (ld. Függvénytáblázat vagy az Intézet által kiadott Képletgyüjtemény) éppen $\sin \left(\omega t+\varphi_{0}\right)$, az átfogónak megfelelő kifejezést pedig $A$-val jelölve (1)-et kapjuk. Tehát a kezdeti feltételekből a mozgás amplitúdója és kezdőfázisa az alábbi két összefüggéssel határozható meg:

$$
\begin{aligned}
& A=\sqrt{x_{0}^{2}+\left(\frac{v_{0}}{\omega}\right)^{2}}, \\
& \operatorname{tg} \varphi_{0}=\frac{x_{0}}{\frac{v_{0}}{\omega}}=\frac{x_{0} \omega}{v_{0}} .
\end{aligned}
$$

Megjegyzés: Az előbbi gondolatmenet az alábbi trigonometrikus azonosság levezetésének egy speciális esete:

$$
a \cos \gamma+b \sin \gamma=c \sin (\gamma+\alpha)
$$

ahol

$$
\begin{gathered}
c=\sqrt{a^{2}+b^{2}}, \\
\operatorname{tg} \alpha=\frac{a}{b} .
\end{gathered}
$$

Felmerülhet az a kérdés is, hogy ha eddig a rugóra akasztott test mozgását úgy figyeltük meg, hogy a rugó függőleges helyzetủ volt (nyilván, hiszen így a legegyszerübb bemutatni a rezgést), akkor miért nem így tárgyaljuk a dinamikáját is. Tárgyalhatnánk így is, mint ahogyan 
a [9] videóban Papp György is tárgyalja, de akkor a mozgó testre nem csak a rugóerő hat, hanem az $m g$ nagyságú, lefelé irányuló nehézségi erő is. Ezzel együtt kell felírni a dinamika alapegyenletét úgy, hogy most az $x$-tengely kezdőpontját nem a rugó nyújtatlan állapotában, hanem a test egyensúlyi helyzetében vesszük fel. Egyszerüsítések után a megoldandó differenciálegyenlet ugyanaz lesz, mint a vízszintes esetben volt, csak a rezgés középpontja tolódik el a nyújtatlan állapotból az egyensúlyi állapotba.

Hallgatóink legközelebb közel fél év múlva találkoznak újra a harmonikus rezgőmozgással, immár fizika órákon. Itt a [9]-hez hasonló élvezetes elöadásban lehet részük, de ugyanezt a levezetést megtalálhatjuk a [10] és [11] interneten elérhető tananyagokban is.

Itt az előadó illetve a szerzők a differenciálegyenlet megoldásának mélyebb szintjére nyúlnak vissza. Hallgatóinknak mindössze annyi elöismerete van, hogy az $y(x)$ függvényre felírt másodrendü, lineáris, állandó együtthatós homogén differenciálegyenlet megoldása során a karakterisztikus egyenlet két valós $\left(\lambda_{1}\right.$ és $\left.\lambda_{2}\right)$, egy valós $(\lambda)$ vagy két komplex $\left(\lambda_{1,2}=\alpha \pm\right.$ $\beta i$ ) gyökét e három esetnek megfelelöen rendre az

$$
\begin{gathered}
y(x)=c_{1} e^{\lambda_{1} x}+c_{2} e^{\lambda_{2} x}, \\
y(x)=c_{1} e^{\lambda x}+c_{2} x e^{\lambda x}, \\
y(x)=e^{\alpha x}\left[c_{1} \cos (\beta x)+c_{2} \sin (\beta x)\right]
\end{gathered}
$$

képletekbe kell behelyettesíteni ([8] 71-72. old.). Az, hogy miért, annak levezetése ma már nem képezi a matematika tárgy anyagát. Több mint tíz évvel ezelőtt, amikor még magasabb óraszámban hallgathatták egyetemünk hallgatói a matematikát, a második szemeszterben oktatott Matematika II. tárgy akkor használatos jegyzetében a levezetés szerepelt ([12] 265267. old.), és számonkért tananyag volt. Habár a differenciálegyenletek oktatása már akkor sem feltétlenül előzte meg azokat a fizika előadásokat, ahol már alkalmazásuk is előkerült, tehát a megértést legfeljebb utólag segíthette. Sajnos a több mint tíz éve tartó ismételt oktatás átszervezések, tantervi háló módosítások és a matematika tárgyainak, óraszámainak folyamatos és drasztikus csökkentése révén sok értékes és hasznos tananyag kikerült az oktatott témák közül. Többek között a (9)-(11) képletek levezetése és a komplex számok Euler-alakja is. Az utóbbi egyik fontos alapismeret az előbbi megértéséhez. Így a fizika előadáson elhangzókhoz hiányoznak azok az előismeretek, amelyek alapján a hallgató követni tudná az ottani gondolatmenetet. A [9]-ben elhangzó és [10], [11]-ben olvasható levezetést szeretném most kiegészíteni, remélve, hogy ez segítséget jelent a hallgatóknak a könnyebb megértéshez.

A kérdés végeredményben az, hogy hogyan kapjuk a (3) karakterisztikus egyenlet két komplex gyökéből az (5) függvényt mint a (2) egyenlet általános megoldását? A problémát vizsgáljuk kicsit általánosabban, amikor is a kiinduló differenciálegyenletből nem hiányzik a keresett függvény első deriváltjával arányos tag sem. Annál is inkább indokolt ez a bővebb vizsgálat, mivel a csillapított rezgések egyik típusának is pontosan ilyen alakú a mozgásegyenlete. Általánosan egy $x(t)$ függvényre felírt másodrendű, lineáris, állandó együtthatós homogén differenciálegyenlet megoldását az

$$
x(t)=e^{\lambda t}
$$

alakban keressük. Ennek kétszeri deriválásával és a kiinduló egyenletbe való behelyettesítésével, $e^{\lambda t}$ kiemelésével kapjuk a karakterisztikus egyenletet, melynek a megoldása abban az esetben, ha a diszkrimináns negatív, két komplex szám, amelyek egymásnak konjugáltjai. Általános alakjuk:

$$
\lambda_{1,2}=\alpha \pm \beta i
$$


Így az $e^{\lambda t}$ alakban keresett két független megoldás

$$
\begin{aligned}
& \bar{x}_{1}(t)=e^{(\alpha+\beta i) t}, \\
& \bar{x}_{2}(t)=e^{(\alpha-\beta i) t} .
\end{aligned}
$$

A felülvonás arra utal, hogy a megoldások komplex függvények.

A hallgatóban joggal merül fel a kérdés, hogy hogyan értelmezzük ezeket a kifejezéseket. Itt merül fel a komplex számok Euler-alakja ismeretének az igénye.

Kitérő: A komplex számok Euler-alakja. Ehhez az $e^{x}$ függvény MacLaurin-soráig kell visszanyúlnunk ([8] 35. old.):

$$
e^{x}=1+x+\frac{x^{2}}{2 !}+\frac{x^{3}}{3 !}+\frac{x^{4}}{4 !}+\cdots
$$

Ebből a sorból származtathatjuk az $e^{i x}$ sorát ([13] 105. old. és pl. [14] 152. old.) oly módon, hogy a sorban $x$ helyére $i x$-et írunk:

$$
e^{i x}=1+i x+\frac{(i x)^{2}}{2 !}+\frac{(i x)^{3}}{3 !}+\frac{(i x)^{4}}{4 !}+\cdots
$$

A számlálókban tényezőnként elvégezzük a hatványozást. A páros kitevőjü hatványokat tartalmazó tagok valósak lesznek váltakozó elöjellel, aszerint, hogy az $i$ kitevője néggyel osztva 2 vagy 0 maradékot ad-e. A páratlan kitevőjü tagok együtthatói viszont $+i$ vagy $-i$ lesznek, attól függően, hogy a kitevő néggyel osztva 1 vagy 3 maradékot ad-e.

$$
e^{i x}=1+i x-\frac{x^{2}}{2 !}-i \frac{x^{3}}{3 !}+\frac{x^{4}}{4 !}+i \frac{x^{5}}{5 !}-\frac{x^{6}}{6 !}-i \frac{x^{7}}{7 !} \pm \cdots .
$$

Ez alapján a sor felírható egy csak valós és egy csak képzetes tagokat tartalmazó részsor összegeként:

$$
e^{i x}=\left(1-\frac{x^{2}}{2 !}+\frac{x^{4}}{4 !}-\frac{x^{6}}{6 !} \pm \cdots\right)+i\left(x-\frac{x^{3}}{3 !}+\frac{x^{5}}{5 !}-\frac{x^{7}}{7 !} \pm \cdots\right)
$$

Az első zárójelben (valós tagok) szereplő sor éppen a $\cos x$, a második zárójelben (képzetes tagok) lévő sor pedig a $\sin x$ függvény MacLaurin-sora:

$$
e^{i x}=\cos x+i \sin x .
$$

Ezt az összefüggést Euler-egyenletnek hívjuk ([14] 152-153. old.) Ez alapján az $e^{\alpha+\beta i}$ exponenciális alakban megadott komplex szám a következő módon írható fel trigonometrikus alakban:

$$
e^{\alpha+\beta i}=e^{\alpha} \cdot e^{\beta i}=e^{\alpha}(\cos \beta+i \sin \beta)
$$

Az $e^{\alpha}$ pozitív valós szám éppen a komplex szám abszolút értéke, $\beta$ pedig az argumentuma. Ezeket rendre a szokásos $r$-rel és $\varphi$-vel jelölve a trigonometrikus és az exponenciális alak közötti összefüggés felírható az

$$
r(\cos \varphi+i \sin \varphi)=r e^{i \varphi}
$$

alakban. A jobb oldalon szereplő exponenciális alakot nevezik a komplex számok Euleralakjának. 
Mindkét alak a szám abszolút értékéről és argumentumáról hordoz információt. Az Euleralakkal a komplex számok szorzására, osztására, hatványozására vonatkozó szabályok annyival egyszerübben levezethetők, mint amennyire az azonos alapú hatványokra vonatkozó azonosságok egyszerübbek a trigonometrikus azonosságoknál. Előnye még, hogy alkalmazásához kevesebb karakter leütése (leírása) szükséges.

Szakirodalmakban a szinuszosan váltakozó mennyiségek komplex számokkal történő leírása esetén egyszerübb kezelése miatt gyakrabban alkalmazzák az Euler-alakot, mint a trigonometrikust (ld. pl. [7] 9-10. old. és [14] 38. old.).

A matematikai kitérő után térjünk vissza a lineáris differenciálegyenlet (12) szerinti két független megoldására. Ezek a következő alakban írhatók fel:

$$
\begin{aligned}
& \bar{x}_{1}(t)=e^{\alpha t} \cdot e^{i \beta t}=e^{\alpha t}[\cos (\beta t)+i \sin (\beta t)], \\
& \bar{x}_{2}(t)=e^{\alpha t} \cdot e^{-i \beta t}=e^{\alpha t}[\cos (-\beta t)+i \sin (-\beta t)]=e^{\alpha t}[\cos (\beta t)-i \sin (\beta t)] .
\end{aligned}
$$

A második megoldásnál kihasználtuk a koszinusz függvény páros, a szinusz függvény páratlan voltát. Ha egy komplex függvény megoldása a valós együtthatós lineáris egyenletnek, akkor [12] 267. oldala alapján annak valós és képzetes része külön-külön is megoldásai az egyenletnek. Így a két független, most már valós megoldás:

$$
\begin{aligned}
& x_{1}(t)=e^{\alpha t} \cos (\beta t) \\
& x_{2}(t)=e^{\alpha t} \sin (\beta t) .
\end{aligned}
$$

Ezek lineáris kombinációi adják a kiinduló differenciálegyenlet általános megoldását:

$$
x(t)=e^{\alpha t}\left[c_{1} \cos (\beta t)+c_{2} \sin (\beta t)\right],
$$

ami éppen a (11) összefüggés. A csillapítatlan szabadrezgés (2) mozgásegyenlete (3) szerinti karakterisztikus egyenletének (4) komplex gyökeinek zérus a valós része, így a két független megoldásból az exponenciális tényező kiesik, így kapjuk (5)-öt általános megoldásként.

A [9] előadáson a lineáris differenciálegyenlet általánosan levezetett végképletébe való behelyettesítés helyett egy másik gondolatmenettel jutunk a harmonikus rezgőmozgás (1) végeredményéhez. A karakterisztikus egyenlet (4) szerinti két komplex megoldását egyből az $e^{\lambda t}$ alakban keresett megoldásba helyettesítjük, és ezek lineáris kombinációiként keressük az adott kezdeti feltételeket is kielégítő valós megoldást:

$$
x(t)=c_{1} e^{i \omega t}+c_{2} e^{-i \omega t}
$$

Az így felírt általános megoldásban viszont a konstansoknak is komplexeknek kell lenniük, hogy a végeredmény valós legyen, ami hallgatóink számára meglepő lehet, hiszen ilyesmivel nem találkoztak matematika órákon.

A konstansok meghatározása kétféle módon is történhet. Az egyik az, ahogyan a fizika előadáson láthatjuk. Ez esetben a két konstanst a

$$
\begin{aligned}
& c_{1}=\frac{a}{2 i} e^{i \alpha} \\
& c_{2}=-\frac{a}{2 i} e^{-i \alpha}
\end{aligned}
$$

alakban vesszük fel. Miért? Mert ez vezet célhoz. Ez is „lóg a levegőben”, egyszerüen be kell magolni az alakot. Ezt (14)-be helyettesítve, $a$-t kiemelve, az exponenciális tényezőket összevonva, végül felhasználva a 


$$
\begin{aligned}
& \cos x=\frac{e^{i x}+e^{-i x}}{2} \\
& \sin x=\frac{e^{i x}-e^{-i x}}{2 i}
\end{aligned}
$$

azonosságok közül az utóbbit, adódik az

$$
x(t)=a \sin (\omega t+\alpha)
$$

partikuláris megoldás. Ez alakilag ugyanaz, mint (1), $a$-val az amplitúdót, $\alpha$-val a kezdőfázist jelöltük.

Az a kis hiányosság van még a levezetésben, hogy a matematikai „emlékeztető”-ként felírt (15) azonosságok szintén nem fordulnak elő matematika órán, tehát elvileg nem tekinthetjük ismertnek. A (13) Euler-egyenletet $e^{-i x}$-re is felírva az

$$
\left.\begin{array}{l}
e^{i x}=\cos x+i \sin x \\
e^{-i x}=\cos x-i \sin x
\end{array}\right\}
$$

két egyenlet adódik. Ezeket összeadva és kivonva egymásból, és a kapott egyenleteket rendre 2-vel és $2 i$-vel elosztva kapjuk a (15) azonosságokat.

A (14) általános megoldásban a $c_{1}$ és $c_{2}$ konstansokat az elsőre talán légből kapottnak tünő felvétel helyett a már ismertetett módon a (6) szerinti

$$
\left.\begin{array}{l}
x(0)=x_{0} \\
v(0)=v_{0}
\end{array}\right\}
$$

két kezdeti feltétel behelyettesítésével is meghatározhatjuk. Az első feltételből a

$$
c_{1}+c_{2}=x_{0}
$$

egyenlet adódik. A második feltétel felhasználásához (14)-et deriválva kapjuk a sebességet:

$$
v=\dot{x}(t)=c_{1} i \omega e^{i \omega t}-c_{2} i \omega e^{-i \omega t} .
$$

Ebbe helyettesítjük be a második feltételt, amire a

$$
c_{1}-c_{2}=\frac{v_{0}}{i \omega}=-\frac{v_{0}}{\omega} i
$$

egyenlet adódik. Ezt és (16)-ot mint egyenletrendszert megoldva kapjuk a két konstanst:

$$
\begin{aligned}
& c_{1}=\frac{x_{0}}{2}-\frac{v_{0}}{2 \omega} i \\
& c_{2}=\frac{x_{0}}{2}+\frac{v_{0}}{2 \omega} i .
\end{aligned}
$$

Ezeket a (14) általános megoldásba helyettesítjük, az exponenciális tényezőket átírjuk trigonometrikus alakba, majd a beszorzásokat elvégezve, összevonva pontosan a (7) partikuláris megoldást kapjuk. Innen az amplitúdóval és kezdőfázissal megadott megoldást a fent ismertetett átalakítással tehetjük meg.

Ezekkel a kiegészítésekkel remélhetőleg sikerült a harmonikus rezgőmozgás tárgyalása során ismertetett levezetéseket érthetőbbé tenni, az ehhez szükséges matematikai ismereteket kipótolni. 
Megjegyzés: Most ugyan csak a rugóra akasztott test mozgását vizsgáltuk, de ugyanúgy harmonikus rezgőmozgás alakul ki minden, a rugóerőhöz hasonló alakú erő hatására. Ezeknek az erőknek többféle megnevezése ismert: rugalmas erő, harmonikus erő, kvázielasztikus erő. Ha a lineáris harmonikus rezgőmozgást általánosabban akarjuk tárgyalni, akkor a rugóra jellemző rugóállandó $D$ jele helyett gyakran alkalmazzák a $k$ jelölést mint arányossági tényezőt $(F=-k x)$, amely mozgástípustól függően más és más fizikai tartalommal bír. Bármilyen harmonikus rezgést vizsgálunk is, a mozgás differenciálegyenlete minden esetben (2) alakúra hozható. Az állítás fordítva is igaz, minden olyan mozgás, amelynek a differenciálegyenlete (2) alakúra hozható, harmonikus rezgőmozgás lesz, melynek a megoldása (1) alakú, ahol $A$-t és $\varphi_{0}$-t a kezdeti feltételekből határozhatjuk meg.

\section{3. Összefoglaló}

A harmonikus rezgőmozgás legegyszerübb típusának példáján keresztül mutattam rá arra, hogy milyen sok matematikai elöismeret szükséges egy-egy tantárgy témáinak megértéséhez. Az adott tárgyalásmód sok esetben olyan ismeretekre is épül, amelyeknek a hallgató önhibáján kívül nincs a birtokában. Tanuláselméleti kutatások bizonyítják, hogy az új anyag akkor sajátítható el könnyen és jól, ha a tanuló fejében már vannak olyan elöismeretek, amelyekhez lehet azt kötni. Ezek hiányában az új anyag lóg a levegőben, megértése és beépülése helyett bemagolással tanulható meg, amely így alapok nélküli, rövidéletü tudást eredményez.

A harmonikus rezgőmozgást megértve elsajátítani akaró tanuló fejében számos ponton merülhet fel hiányérzet és ehhez kapcsolódó kérdés. Első az, hogy a matematika órákon példaként bemutatott differenciálegyenlet megoldása miért nem egyezik a középiskolában tanulttal? A következő pedig: a fizika órán bemutatott megoldási módszer miért tér el a matematikából tanulttól? Ha ott úgy tanították, akkor itt miért nem úgy alkalmazzuk? És fordítva: ha itt így alkalmazzuk, akkor ott miért nem ezt a módszert tanították? Hogyan értelmezzük az $e^{i \omega t}$ kifejezést?

Bízom benne, hogy a komplex számok Euler-alakjának bemutatásával és a többi kisebb kiegészítéssel sikerült a hiányzó ismereteket pótolni, a kétféle megoldási módszert összeegyeztetni. A csillapodó rezgések és a kényszerrezgések tárgyalása ezekkel a kiegészítésekkel már könnyebben érthető, és így talán hallgatóink sem félnek majd e három tétel közül húzni.

\section{Köszönetnyilvánítás}

Ezúton szeretném megköszönni egykori tanáromnak és témavezetőmnek, Dr. Papp Györgynek, hogy annak idején rám bízta a csillapodó rezgőmozgások című előadás megtartását és ehhez rendelkezésemre bocsátotta saját jegyzeteit.

\section{Irodalomjegyzék}

[1] Geomatech, Gulyás E., Éder O., Muskovits I., A harmonikus rezgőmozgás és a körmozgás kapcsolata, https://www.geogebra.org/m/vdbzaT4D\#material/fRJTxioP

[2] Sulinet, Fizika, A kitérés-idő függvény és a harmonikus rezgőmozgás, https://tudasbazis.sulinet.hu/hu/termeszettudomanyok/fizika/fizika-9-evfolyam/a-kiteres-ido-fuggveny-esa-harmonikus-rezgomozgas/a-harmonikus-rezgomozgas-es-a-kormozgas-kapcsolata

[3] Holics, L., Fizika, gimnázium III. osztály, Tankönyvkiadó, Budapest (1986), 7-37.

[4] Dégen, Cs., Elblinger, F., Simon, P., Fizika 11 a középiskolák számára, Oktatáskutató és Fejlesztő Intézet, Budapest (2015), 13-17. 
[5] Geomatech, Harmonikus rezgőmozgás és körmozgás kapcsolata (Extra) https://www.geogebra.org/m/vdbzaT4D\#material/YhN2jtm0

[6] Budó, Á., Kísérleti fizika I., Tankönyvkiadó, Budapest, 1986.

[7] Bosznay, Á., Mechanikai lengéstan I-II., Kézirat, Budapesti Müszaki Egyetem Villamosmérnöki Kar, Tankönyvkiadó, Budapest, 1961.

[8] Barta, E., Nagy, Zs., Salay, L., Matematika 1.: EMK/SKK - BSc, Sopron, Magyarország: Soproni Egyetem Kiadó, 2018.

[9] Papp Gy., Rezgőmozgás, https://www.youtube.com/watch?v=AlIUPVphuXM

[10] http://elmmech.uw.hu/elmfejezet2.html

[11] Gyémánt I., Elméleti mechanika, Második fejezet: Rezgések, 2008. http://titan.physx.u-szeged.hu/ gyemant/02.pdf

[12] Horváth, J., Matematika II. Soproni Egyetem, Sopron, 1998.

[13] Horváth, J., Matematika I. Soproni Egyetem, Sopron,1998.

[14] Standeisky, I., Villamosságtan, Universitas-Győr Kht., Győr, 2005. 